\title{
ŚLUBY I POGRZEBY W KSIĘDZE ACTA PONTIFICIA BISKUPA KRAKOWSKIEGO JANA ALEKSANDRA LIPSKIEGO (Z ŻYCIA RELIGIJNEGO I TOWARZYSKIEGO ELIT STAROPOL- SKICH DOBY SASKIEJ)
}

Jedyny purpurat w gronie XVIII-wiecznego episkopatu katolickiego Rzeczypospolitej Obojga Narodów, kardynał Jan Aleksander Lipski (1690-1746), od objęcia przez którego stolicy św. Stanisława mija właśnie 277 lat, należy do postaci dobrze znanych badaczom nowożytnych dziejów Polski, a zwłaszcza Krakowa ${ }^{1}$. Jakkolwiek dotychczas jeszcze nie doczekał się on naukowej biografii, ujmującej całokształt jego drogi życiowej i dokonań, tym niemniej same jako takie rządy pasterskie Lipskiego w diecezji krakowskiej, przypadające na lata 1732/17331746, stały się przedmiotem osobnej monografii - zresztą stosunkowo świeżej daty $^{2}$. Jej autor, ks. Józef Bendyk, wykorzystał obfitą podstawę źródłową (jakkolwiek ograniczył się przy tym niemal wyłącznie do zbiorów archiwalnych przechowywanych w Krakowie), sięgając także do rękopiśmiennego kodeksu Acta

${ }^{1}$ Zob. m.in. J. Gierowski, Lipski Jan Aleksander herbu Grabie (1690-1746), podkanclerzy koronny, biskup krakowski, kardynat, w: Polski Stownik Biograficzny [dalej: PSB], t. 17, Wrocław 1972, s. 425-431; B. Brzuszek, Lipski Jan Aleksander herbu Grabie (1690-1745), biskup krakowski $i$ kardynat, autor listu pasterskiego o treści teologicznej, w: Słownik polskich teologów katolickich, t. 2, red. H. E. Wyczawski, Warszawa 1982, s. 534-536; B. Kumor, Dzieje diecezji krakowskiej do roku 1795, t. 1, Kraków 1998, s. 529-530; K. R. Prokop, Poczet biskupów krakowskich, Kraków 1999, s. 193-196; tenże, Polscy kardynałowie, Kraków 2001, s. 157-165; tenże, Sylwetki biskupów tuckich, Biały Dunajec - Ostróg 2001, s. 138-145; B. Kumor, Lipski Jan Aleksander, kardynat, w: Encyklopedia Katolicka, t. 10, Lublin 2004, kol. 1128 (gdzie wskazana dalsza literatura). Ogólnie do genealogii Lipskich herbu Grabie zob. także: K. Niesiecki, Herbarz polski, t. 6, Lipsk 1841, s. 107-116; T. Żychliński, Złota księga szlachty polskiej, t. 1, Poznań 1879, s. 138-153; A. Boniecki, Herbarz polski, t. 14, Warszawa 1911, s. 320-335; S. Uruski, Rodzina. Herbarz szlachty polskiej, t. 9, Warszawa 1912, s. 91-100; M. Adamczewski, Lipscy herbu Grabie w świetle źródet epigraficznych w kolegiacie w Choczu, w: Studia z dziejów feudalizmu, red. S. M. Zajączkowski (Acta Universitatis Lodziensis. Folia Historia, 50), Łódź 1994, s. 107-129.

${ }^{2}$ J. Bendyk, Działalność duszpasterska biskupa Jana Aleksandra kardynała Lipskiego w diecezji krakowskiej w latach 1732-1746, Kraków 1997. 
pontificia Celsissimi, Illustrissimi et Reverendissimi Domini Joannis in Lipe Lipski, episcopi Cracoviensis, ducis Severiae, procancellarii Regni Poloniae ${ }^{3}$, z którego też zaczerpnięta została większość materiału ilustracyjnego, zaprezentowanego w rzeczonej publikacji ${ }^{4}$. Zabytek ów znajduje się aktualnie w Archiwum Kapituły Metropolitalnej na Wawelu, jako prawdopodobnie jedyna w tamtejszym zasobie księga reprezentująca gatunek Libri sacrarum ordinationum (Libri functionum pontificalium $)^{5}$. Do naszych czasów dotrwało wprawdzie kilkanaście innych ksiagg czynności pontyfikalnych biskupów krakowskich (głównie zresztą sufraganów), wszystkie one jednak przechowywane są w Archiwum Kurii Metropolitalnej w Krakowie, gdzie tworzą osobny $\mathrm{dział}^{6}$, nadto zaś pojedynczą posiada

${ }^{3}$ Tamże, s. $184-187$.

${ }^{4}$ Tamże, s. 14-15, 18, 25-27, 106, 151, 167, 171, 175 oraz pierwsza strona okładki.

${ }^{5}$ Archiwum Kapituły Metropolitalnej w Krakowie [dalej: AKapMK], sygn. LA 36 - Acta pontificia Celsissimi, Illustrissimi et Reverendissimi Domini, Domini Joannis in Lipe Lipski, episcopi Cracoviensis, ducis Severiae, procancellarii Regni Poloniae, ab exordio pontificatus eiusdem electi et consecrati in episcopum Luceoriensem, usque ad praesens temporis spatium conscripta ab anno Domini 1734. Zob. również: I. Polkowski, Katalog rękopisów kapitulnych katedry krakowskiej, cz. 1 - Kodexa rękopiśmienne 1-228, Kraków 1884.

${ }^{6}$ Archiwum Kurii Metropolitalnej w Krakowie [dalej cyt.: AKMK], sygn. LOrd 4-18. Dla doby staropolskiej są to następujące księgi z rzeczonego zespołu: sygn. LOrd 4 - Liber ordinatorum, consecrationis ecclesiarum, capellarum, altarium, portatilium per Reverendissimum Albertum Lipnicki, [...] episcopum Laodicensem, suffraganeum, canonicum, vicarium in spiritualibus et officialem generalem Cracoviensem • Liber ordinatorum, consecrationis ecclesiarum, capellarum, caemiteriorum, campanarum, altarium immobilium et portatilium ac calicium per Reverendissimum $\mathrm{Ni}$ colaum Oborski, [...] episcopum Laodicensem, suffraganeum, archidiaconum, in spiritualibus vicarium et officialem generalem Cracoviensem; sygn. LOrd 5 - Liber ordinatorum, consecrationis ecclesiarum, capellarum, altarium immobilium, portatilium et calicium per Reverendissimum Dominum Nicolaum Oborski, [...] episcopum Laodicensem, suffraganeum, scholasticum, in spiritualibus vicarium et officialem generalem Cracoviensem; sygn. LOrd 6 - Liber ordinatorum, consecrationis ecclesiarum, capellarum, altarium immobilium, portatilium, calicium et campanarum per Illustrissimum et Reverendissimum Dominum Stanislaum a Stupow Szembek, [...] episcopum Dionisiensem, suffraganeum [...] Cracoviensem, anno Domini 1695oㅡ inceptus; sygn. LOrd 7 - Liber ordinatorum, consecrationis ecclesiarum, capellarum, altarium immobilium, portatilium, calicium et campanarum per Illustrissimum et Reverendissimum Dominum Casimirum a Łubna Lubienski, [...] episcopum Chelmensem, canonicum, sede vacante episcopatus Cracoviensis ac ducatus Severiae generalem administratorem, perpetuum commendatarium abbatem Czerviensem $\bullet$ Functionum episcopalium per eundem Illustrissimum et Reverendissimum Dominum Casimirum a Łubna Eubienski post apprehensam feliciter [...] possessionem episcopatus Cracoviensis peractarum, connotatio; sygn. LOrd 8 - Acta pontificalium functionum peractarum in dioecesi Cracoviensi $[\ldots]$ ab Illustrissimo et Reverendissimo Domino Stanislao Josepho Hosio, episcopo Uticensi, suffraganeo Praemisliensi, canonico et administratore generali Cracoviensi $\bullet$ Acta pontificalia Celsissimi Principis, Illustrissimi et Reverendissimi Domini Constantini Feliciani Szaniawski, episcopi Cracoviensis, ducis Severiae; sygn. LOrd 9 - Liber ordinatorum, consecrationis ecclesiarum, capellarum, altarium immobilium, portatilium, calicium et campanarum per Illustrissimum et Reverendissimum Dominum Michaelem Kunicki, [...] episcopum Arsinoensem, suffraganeum et archidiaconum Cracoviensem, custodem Sandomiriensem - Ordinationes per Eminentissimum, Celsissimum, Illustrissimum ac Reverendissimum olim cardinalem Joannem Lipski, episcopum Cracoviensem, intra 
Archiwum Kapituły Katedralnej w Sandomierzuํ. Spośród nich ta z Wawelu wyróżnia się zarówno wysmakowaną estetyką, gdy chodzi o aspekt szaty graficznej (wspomniany tu wyżej materiał ilustracyjny, który stanowi raczej rzadkość w tego typu rękopisach, zdobionych co najwyżej herbem biskupim właściciela), jak i stosunkowo niepokaźną liczbą zapisek. Ta ostatnia okoliczność nie powinna nadmiernie dziwić, jako że w dobie przedrozbiorowej pasterze diecezji katolickich obrządku łacińskiego z obszaru rozległej ówcześnie Rzeczypospolitej Obojga Narodów byli przede wszystkim mężami stanu, czynnie zaangażowanymi w życie polityczne kraju (zasiadali wszak w Senacie tudzież piastowali urzędy państwowe, z których część była dostępna - choć nie zarezerwowana - także dla osób duchownych), w mniejszym natomiast stopniu udzielali się w ściśle pojmowanej sferze religijnej, w sprawowaniu posług pontyfikalnych zdając się najczęściej na biskupów pomocniczych (przede wszystkim sufraganów, ale bywało, że i innych tytulariuszy, nie ,przypisanych" w równie formalny sposób, co tamci, do konkretnej diecezji). Stąd też nie tak często byli oni szafarzami święceń, co dziś wszak stanowi coś oczywistego w odniesieniu do każdego ordynariusza, podobnie jak tylko w wybranych przypadkach podejmowali się dokonywania poświęceń miejsc i przedmiotów kultu (świątyń, kaplic, ołtarzy, dzwonów, itd.). Jeśli już to czynili, okoliczność ta pozostawała często w związku z przesłankami zupełnie innej natury, aniżeli aspekt duszpasterski (np. wzgląd na osobę fundatora kościoła czy też właściciela dóbr, na terenie których znajdował się dany obiekt - zazwyczaj zresztą chodziło o jedną i tę samą personę). Nie inaczej rzecz przedstawiała się w przypadku szafowania sakramentów, mianowicie chrztu, bierzmowania i małżeństwa, tudzież przewodniczenia ceremoniom pogrzebowym. Tylko w przypadku sakramentu dojrzałości chrześcijańskiej (nie wspominając o kolejnych stopniach święceń) nieodzowny był udział biskupa, jako szafarza, w czego konsekwencji i ten obowiązek obciążał najczęściej sufraganów. Ewentualny udział w uroczystościach chrzcielnych, weselnych czy żałobnych tego lub innego pasterza diecezji, podobnie jak udzielenie przezeń komuś bierzmowania, stanowiło zazwyczaj pochodną jakichś szczególniejszego rodzaju powiązań czy relacji, łączących danego hierarchę z konkretną osobą lub jej kręgiem rodzinnym (najczęściej chodziło

et extra dioecesim Cracoviensem factae; sygn. LOrd 10 - Acta Illustrissimi et Reverendissimi Domini Francisco de Potkana Potkanski, episcopi Patarensis, suffraganei, canonici, vicarii in spiritualibus et officialis generalis Cracoviensis; sygn. LOrd 12 - [Liber ordinatorum per Illustrissimum et Reverendissimum Dominicum Josephum Kiełczewski, episcopum Hermopolitanum, suffraganeum Chelmensem]; sygn. LOrd 13 - Acta functionum episcopalium Illustrissimi et Reverendissimi Domini Josephi Olechowski, [...] episcopi Uranopolitani, suffraganei et archidiaconi cathedralis Cracoviensis, collegiatae Sandomiriensis custodis, curiae episcopalis auditoris et iudicis generalis. Ogólnie o księgach tych pisał J. Kracik, Zasoby Archiwum Kurii Metropolitalnej w Krakowie, „Analecta Cracoviensia", 9 (1977) s. 479-480. Zob. również: tenże, Księgi święceń i konsekracji jako źródto historyczne, „Notificationes e Curia Metropolitana Cracoviensi”, 119 (1981) nr 7-9, s. 216-222; H. E. Wyczawski, Przygotowanie do studiów w archiwach kościelnych, Kalwaria Zebrzydowska 1989 , s. 254-256.

${ }^{7}$ Archiwum Kapituły Katedralnej Sandomierskiej, rkp 127 - Acta functionum episcopalium Illustrissimi et Reverendissimi Domini Adalberti Josephi Boxa Radoszewski, [...] episcopi Hirinensis, suffraganei noviter erecti Sandomiriensis, praepositi infulati Klimuntoviensis, in Iwaniska curati. 
o więzy natury genealogicznej, choć w uprzywilejowanej sytuacji byli też nawet niespokrewnieni z biskupem jego domownicy $)^{8}$.

Już z tego chociażby względu zawarte w nie tak znów licznie zachowanych księgach czynności pontyfikalnych biskupów rezydencjalnych z doby staropolskiej spisy osób, które dostąpiły zaszczytu ochrzczenia (czy też dokonywanego niekiedy w późniejszym terminie tzw. dopełnienia ceremonii chrzcielnych) ${ }^{9}$, bierzmowania lub pobłogosławienia ich małżeństwa przez pasterza diecezji, podobnie jak przypadki udziału tegoż w czyichś uroczystościach żałobnych (albo odprawienie egzekwii), zasługują na baczniejszą uwagę ze strony nie tylko badaczy ówczesnej religijności lub genealogów, ale również historyków zainteresowanych problematyką społeczna, zagadnieniami demograficznymi czy też dziejami kultury (w tym i kultury materialnej). W zestawieniu $\mathrm{z}$ wydawanymi niekiedy na owe okazje panegirykami, tudzież relacjami publikowanymi w prasie periodycznej (w przypadku Polski mowa zatem o okresie począwszy od roku 1729), świadectwa te pozwalają na poszerzenie naszej wiedzy o elitach społeczeństwa staropolskiego (zasadniczo bowiem ich tylko dotyczą owe przekazy) zarówno w aspekcie ściśle pojmowanej faktografii (chronologia wydarzeń), jak i panoramy ówczesnej obyczajowości.

Wspominając o pożytkach płynących z analizy tudzież publikacji materiałów zawartych w księgach czynności pontyfikalnych biskupów z doby przedrozbiorowej, trudno nie nadmienić również o ich pomocniczej roli przy odtwarzaniu itinerarium konkretnego hierarchy. Opierając się wyłącznie na wpisach w zespole

${ }^{8}$ Por. Bendyk, Działalność duszpasterska, s. 37-42 (gdzie m.in. poglądowe zestawienia tabelaryczne). Zob. także: J. Kracik, Konsekracje kościołów i ołtarzy w diecezji krakowskiej w XVII-XVIII wieku, „Nasza Przeszłość”, 61 (1984) s. 111-147; K. R. Prokop, Wiadomości genealogiczne i dotyczqce wydarzeń historycznych w księgach święceń biskupów krakowskich (glównie sufraganów) z drugiej połowy XVII i z XVIII wieku, „Archiwa, Biblioteki i Muzea Kościelne”, 81 (2004) s. 199-223.

${ }^{9}$ Zob. dla przykładu księgę czynności pontyfikalnych blisko związanego z Krakowem, z racji swego pochodzenia, biskupa warmińskiego Krzysztofa Jana Szembeka (nota bene on to właśnie konsekrował w r. 1730 krakowską świątynię karmelitanek bosych na przedmieściu Wesoła): Archiwum Archidiecezjalne w Olsztynie, sygn. AB H 127 - Acta pontificalia peracta a Celsissimo ac Illustrissimo Domino Christophoro Joanne in Stupow Szembek, Dei et Apostolicae Sedis gratia episcopo Varmiensi et Sambiensi, S.R.I. Principe, Terrarum Prussiae praeside, anno Domini millesimo septingentesimo vigesimo quarto, die vigesima septima Decembris [24 XII 1724-14 II 1742], k. 1r-v (dział Baptismus, gdzie na samym początku natrafiamy na interesujący wpis następującej treści: „Anno Domini 1725, die 10 Octobris, Celsissimus, Illustrissimus et Reverendissimus Dominus Christophorus Andreas Joannes comes in Słupow Szembek, episcopus Varmiensis [...], contulit caeremonias baptismi antea baptisatae Illustrissimae Barbarae Szembekowna, Illustrissimorum parentum Francisci Szembek, dapiferi Regni, et Magdalenae, coniugum legitimorum, filiae, agente officium patrini Serenissimo Augusto Secundo, rege Poloniarum, et Illustrissimo Joanne Szembek, supremo Regni cancellario, cum Illustrissima Elisabetha Sieniawska, de domo Lubomirska, castellana Cracoviensi, matrinae officium sustinente, et Illustrissima Theresia Potocka, referendaria Regni. Actus hic celebratus [est] in palatio Celsissimi et Illustrissimi Casimiri Lubomirski, S.R.I. Principis, succamerarii Regni, mariti matris, secundo voto, praedictae filiae, in assistentia multorum senatorum aliarumque personarum, dignitatis praecipuae, Varsaviae, die et anno ut supra."), 151r-v (dział Matrimonium). Por. Prokop, Wiadomości genealogiczne, s. 215-216 oraz niżej przyp. 30 i 32. 
ksiagg Acta episcopalia, przywołany już tu ks. J. Bendyk wyliczył, że w okresie od 1 II 1734 do 20 II 1746 J.A. Lipski w granicach powierzonej mu diecezji spędził w sumie 2756 dni (przy czym w samym Krakowie tylko - w łącznym ujęciu - 25 miesięcy, a więc niewiele ponad dwa lata), natomiast poza nią $-2935 \mathrm{dni}^{10}$. Proporcje owe znajdują odzwierciedlenie i w niżej prezentowanym materiale źródłowym, bowiem spośród 38 uroczystości zaślubin oraz ceremonii żałobnych, którym przewodniczył ów jedyny kreowany w XVIII stuleciu polski purpurat, tylko dziewięć odbyło się w samym Krakowie, dziesięć dalszych w innych miejscowościach na terenie niezwykle wtenczas rozległej diecezji krakowskiej (w tym pięć czy nawet sześć w ulubionych przez Lipskiego Kielcach) ${ }^{11}$, natomiast 19 poza jej granicami, z czego aż $14 \mathrm{w}$ stopniowo wybijającej się na pozycję miasta stołecznego Rzeczypospolitej Obojga Narodów Warszawie, zaś pojedyncza w elektorskim Dreźnie (były to wszak czasy unii personalnej z Saksonia) ${ }^{12}$. Częsta obecność Jana Aleksandra Lipskiego, sprawującego do roku 1735 urząd podkanclerzego koronnego, na dworze królewskim, wokół którego - mimo specyfiki polskiej monarchii o charakterze republiki oligarchicznej - nadal koncentrowało się życie polityczne kraju, podobnie jak długotrwałe bytności w Kielcach, które to miasto upodobał sobie zresztą nie tylko on, ale i niejeden spośród jego poprzedników i następców na stolicy św. Stanisława, zbytnio nie dziwi badacza dziejów Kościoła krakowskiego, bowiem długotrwałe nieobecności w Krakowie pasterza diecezji były w stuleciach XVII i XVIII, a w pewnej mierze także zresztą już i w XVI w., czymś zgoła nagminnym. Zagadnienie to zasługiwało by skądinąd na wnikliwsze przeanalizowanie i omówienie - po uprzednim odtworzeniu itinerariów poszczególnych hierarchów, stanowi ono bowiem ważny aspekt problematyki roli najważniejszych ośrodków miejskich nowożytnej Rzeczypospolitej w życiu polityczno-społecznym oraz religijno-kościelnym kraju, w przypadku Krakowa wskazując na jego stopniowo gasnący w tamtym czasie blask ${ }^{13}$.

${ }^{10}$ Bendyk, Działalność duszpasterska, s. 22-23.

${ }^{11}$ Odnośnie do związków J. A. Lipskiego z Kielcami zob. ostatnio: M. Pieniążek-Samek, Kielce XVII-XVIII wiek. Stownik biograficzny, Kielce 2003, s. 92; M. Pieniążek-Samek, Tributum gratitudinis reddo. Fundacje artystyczne na terenie Kielc w XVII i XVIII wieku. Studium z historii kultury, Kielce 2005, s. 313-314, nr 104.

${ }^{12} \mathrm{~W}$ przedmiocie obecności przedstawicieli polskich elit politycznych w Dreźnie za panowania Augusta II i Augusta III zob. ogólnie J. Staszewski, Polacy w osiemnastowiecznym Dreźnie, Wroclaw 1986.

${ }^{13}$ Do problematyki powolnej utraty w XVII-XVIII w. przez Kraków prerogatyw stołeczności i ich stopniowego przejmowania przez Warszawę, zob. ostatnio: M. Bogucka, Miejsce Warszawy w Polsce w XVI i XVII wieku, w: Warszawa w dziejach Polski, red. M. M. Drozdowski, Warszawa 1998, s. 17-22; J. Lileyko, Sejmy elekcyjne jako podstawowa cecha stołeczności Warszawy w Rzeczypospolitej szlacheckiej, w: Warszawa w dziejach Polski, s. 23-24; Z. Wójcik, Stołeczność Warszawy za panowania Jana III Sobieskiego, w: Warszawa w dziejach Polski, s. 43-50; J. Staszewski, Warszawa w czasach saskich, w: Warszawa w dziejach Polski, s. 65-74; J. Michalski, Nastroje antystołeczne w czasach stanisławowskich, w: Warszawa w dziejach Polski, s. 89-103; B. Grochulska, Miejsce Warszawy w Polsce stanisławowskiej, w: Warszawa w dziejach Polski, s. 105-119. Nadto K. R. Prokop, O utracie stołeczności raz jeszcze, „Kraków. Miesięcznik Społeczno-Kulturalny”, 4 (2007) nr 30, s. 12-14. 
Po tego rodzaju uwagach ogólniejszej natury, pora podzielić się z czytelnikiem informacjami nieco szczegółowszego charakteru. Co się tyczy samego kodeksu, w którym zawarte zostały publikowane powyżej świadectwa źródłowe (nota bene w większości składają się nań niezapisane karty), przechowywany jest on - jak już wspomniano - w Archiwum Kapituły Metropolitalnej na Wawelu pod nadaną mu niedawno nową sygnaturą LA 36 (skrót od Libri Archivi), podczas gdy uprzednio nosił tymczasową sygnaturę I-14 (pod taką też cytuje go J. Bendyk). Widniejące tamże zapiski wyszły spod pióra ks. Jakuba Levisa (Jacobus Levis), kapelana i sekretarza kardynała Lipskiego (o czym informuje nas stosowny wpis w rzeczonym woluminie) ${ }^{14}$, który to duchowny - zgodnie z nadanym rękopisowi tytułem - utrwalił w nim dla potomności wiadomości o posługach pontyfikalnych swego chlebodawcy, a więc dopełnionych przezeń konsekracjach, benedykcjach, święceniach, dalej o udzielaniu chrztów i bierzmowań (w dziale Confirmationes, pośród bierzmowanych przez krakowskiego purpurata, znajdujemy imiona m.in. kilku synów magnackich), błogosławieniu małżeństw, wreszcie też towarzyszeniu w ostatniej drodze (pogrzeby, egzekwie, aniwersarze). Obok tego nie omieszkał odnotować tak ważnych wydarzeń w biografii rzeczonego pasterza, jak jego sakra biskupia (25 V 1732), ingres do katedry na Wawelu (13 I 1733) $)^{15}$, koronacja królewskiej pary Augusta III Wettyna i Marii Józefy Habsburżanki (17 I 1734) ${ }^{16}$, wyróżnienie godnością kardynalską (20 XII 1737) czy wreszcie zgon i pogrzeb

${ }^{14}$ Zob. także Bendyk, Dziatalność duszpasterska, s. 11.

${ }^{15}$ AKapMK, sygn. LA 36, k. 5r („Ascensus Vavellinus Illustrissimi et Reverendissimi Domini, Domini Joannis Alexandri in Lipe Lipski, episcopi Luceoriensis et Brestensis, procancellarii Regni Poloniae, ad episcopatum Cracoviensem anno Domini 1733, die $4^{\text {ta }}$ mensis Februarii [sic]"). Zob. także niżej przyp. 20.

${ }^{16}$ AKapMK, sygn. LA 36, k. 7r („Liber coronationis regum”), 8r („Serenissimi Augusti III., regis Poloniae, una et Serenissimae Mariae Josephae, consortis eiusdem, sacer coronator Illustrissimus et Reverendissimus Dominus, Dominus Joannes Lipski, episcopus Cracoviensis, dux Severiae”), 9r (,In solita coronationis regum Poloniae cathedrae Cracoviensis ecclesia, anno Domini 1734, die 17 mensis Januarii, quae erat Dominica secunda post Epiphaniam, pontifex cathedrae Romano caeremoniarum ritu Serenissimum Augustum Tertium, ducem et electorem Saxoniae, electum regem Poloniarum, una cum Serenissima Maria Josepha, duce [sic] Austriae, eiusdem electi consorte, coronavit, assistentibus coronationi Illustrissimo et Reverendissimo Domino, Domino Stanislao de Bezdan Hosio, episcopo Posnaniensi, Michaele Kunicki, Cracoviensi, Francisco Kobielski, Cuiaviensi, Adamo Grabowski, Posnaniensi, suffraganeis, aliisque plurimis praelatis et canonicis cathedralibus, adstantibus proceribus, ministris Regni, Rei Publicae dignitatibus tam senatorii quam equestris statu, atque ingenti numerositate conventuum populique. [poniżej dopisane inna ręka] Regem coronavit Serenissimum Augustum III, electorem Saxoniae, una cum consorte sua Serenissima Maria Josepha, archiducissa Austriae, in solium Regni Poloniae”). Por. M. Rożek, Ostatnia koronacja w Krakowie i jej artystyczna oprawa, „Rocznik Krakowski”, 44 (1973) s. $97-$ -112; M. Rożek, Uroczystości w barokowym Krakowie, Kraków 1976, s. 156-174; J. Bieniarzówna, J. M. Małecki, Kraków w wiekach XVI-XVIII (Dzieje Krakowa, t. 2), Kraków 1984, s. 458-465; M. Rożek, Polskie korony i koronacje, Kraków 1987, s. 69-70, 150; J. Staszewski, August III Sas, Wrocław 1989, s. 153; Kronika Krakowa, red. J. M. Małecki, A. Kurz i J. Wyrozumski, Warszawa 1996, s. 122; R. Skowron, Wawel. Kronika dziejów, t. 1: Od pradziejów do roku 1918, Kraków 2001, s. 227. 
(20 II/31 III 1746). Zawarte w tymże rękopisie informacje odnośnie do poszczególnych stopni święceń, udzielanych kandydatom do stanu kapłańskiego przez biskupa J.A. Lipskiego (wyłącznie wszakże klerykom kształcącym się w seminariach krakowskich) spożytkował już i - wraz z pokrewnego rodzaju świadectwami - wykorzystał w wydanych przez siebie drukiem katalogach miejscowych alumnów ks. Jan Szczepaniak ${ }^{17}$. Materiał z pozostałych działów Acta pontificia tegoż XVIII-wiecznego hierarchy nie był dotychczas publikowany, przy czym świadectwa dotyczace sakr biskupich (Consecrationes episcoporum ab Illustrissimo et Reverendissimo Domino Joanne episcopo Lipski factae z działu Liber consecrationis episcoporum et benedictionis abbatum) piszący obecne słowa wykorzystał w artykułach i przyczynkach do problematyki sukcesji apostolskiej nowożytnego episkopatu polskiego ${ }^{18}$.

Z lapidarnymi zapiskami o ingresie J.A. Lipskiego do katedry na Wawelu oraz dopełnionej tamże przezeń koronacji Augusta III Wettyna i Marii Józefy Habsburżanki, zainteresowany czytelnik mógł zapoznać się powyżej ${ }^{19}$. W kontekście owej pierwszej nie sposób nie podnieść niezwykle istotnej kwestii stopnia precyzyjności, a w konsekwencji i wiarogodności danych faktograficznych utrwalonych dla potomności przez J. Levisa. Zauważyć mianowicie należy, że podana przezeń data ingresu Jana Aleksandra Lipskiego do wawelskiej świątyni jest błędna, odbył się on bowiem nie w środę 4 II 1733 (jak wyczytujemy na k. 5r Acta pontificia), lecz w oktawę uroczystości Objawienia Pańskiego, tj. we wtorek 13 I tr. ${ }^{20}$ Dziwić może omyłka $\mathrm{w}$ tak istotnej materii w tego rodzaju źródle o charakterze co najmniej na wpoły urzędowym, okazuje się wszakże, iż nie jest ona odosobniona. Nie mniejszą konsternację wzbudza np. wpis odnoszący się do sakry samego owegoż hierarchy, dopełnionej w niedzielę Exaudi 25 V 1732 w kolegiacie św. Jana Chrzciciela w Warszawie, ,,per Celsissimum, Illustrissimum et Reverendissimum Dominum Theodorum Potocki, archiepiscopum Gnesnensem, Primatem Regni Poloniae, assistentibus Illustrissimis et Reverendissimis Dominis Andrea

${ }^{17}$ J. Szczepaniak, Katalog alumnów Seminarium Zamkowego w Krakowie (1677-1801) (Bibliotheca Collectanae Historica, 2), Kraków [Czulice] 2003-2004; J. Szczepaniak, Katalog alumnów Seminarium Stradomskiego (1732-1800) (Bibliotheca Collectanae Historica, 3), Kraków $2006^{2}$. Zob. także AKMK, sygn. LOrd 9 [pełny zapis w przyp. 6], gdzie również odnotowane zostały Ordinationes per [...] olim cardinalem Joannem Lipski, episcopum Cracoviensem, intra et extra dioecesim Cracoviensem factae.

${ }^{18}$ K. R. Prokop, Sakry i sukcesja święceń biskupich pasterzy diecezji płockiej w XVIII wieku, „Studia Płockie”, 34 (2006) s. 207-246; K. R. Prokop, Sakry i sukcesja święceń biskupich pasterzy Kościoła wileńskiego z drugiej oraz trzeciej tercji XVIII stulecia, „Rocznik Teologii Katolickiej”, 5 (2006) s. 211-246; K. R. Prokop, Sakry pasterzy Kościoła przemyskiego w XVIII stuleciu, „Premislia Christiana”, 12 (2006/2007) s. 131-192; K. R. Prokop, Sukcesja święceń biskupich pasterzy Kościoła krakowskiego w XVIII stuleciu, „Analecta Cracoviensia”, 38-39 (2006-2007) s. 513-555.

${ }^{19}$ Zob. wyżej przyp. 15 i 16.

${ }^{20}$ Por. AKapMK, sygn. AAct 21 - [Acta actorum capituli cathedralis Cracoviensis 1731-1746], s. 366 [335]-369 [338]: „Martis 13. Januarii [1734]. Ingressus ad cathedram Celsissimi Principis, Illustrissimi Domini Joanni Alexandri in Lipe Lipski, episcopi Cracoviensis, ducis Severiae, procancellarii Regni Poloniae" (dalej obszerny opis tamtego wydarzenia). Także zob. np. Kumor, Dzieje diecezji krakowskiej, t. 1, s. 530; Skowron, Wawel. Kronika dziejów, t. 1, s. 226. 
Załuski, Plocensi, Nicolao [sic] Wessel, Livoniae, episcopis, Adamo Rostkowski, Luceoriensi, Josepho [sic] Sołtyk, Culmensi, suffraganeis", a to z racji przydania aż w dwóch przypadkach błędnych imion biskupom współkonsekratorom (nie Mikołaj, lecz Adam Augustyn Wessel, i nie Józef, lecz Maciej Aleksander Sołtyk) ${ }^{21}$. Analogicznego charakteru omyłki w materii dat i imion (jeszcze zaś częściej opuszczenie imienia postaci), a obok tego nie zawsze precyzyjne podawanie tytułów tymże osobom przysługujących tudzież piastowanych przez nie godności, trafiają się i w interesujących nas tu działach (przede wszystkim w dziale Benedictiones matrimoniales), co czytelnik łatwo dostrzeże porównując tekst zapisek z informacjami zawartymi przypisach. Odnosi się wrażenie, iż J. Levis nie prowadził księgi Acta pontificia na bieżąco, lecz traktował ją jako czystopis, co jakiś czas uzupełniany o stosowne dane - tyle, że z jakichś względów nie zawsze dysponował pełnym ich zasobem. Dziwić to może, bowiem jako kapelan i sekretarz J. A. Lipskiego zapewne towarzyszył swemu pryncypałowi podczas większości tychże posług biskupich sprawowanych przez pasterza diecezji krakowskiej. Dlaczego zatem brakowało mu później w niektórych przypadkach kompletu danych lub też zawierały one błędne informacje, o jednoznaczną odpowiedź na to pytanie trudno. Tak czy inaczej osoba korzystając $\mathrm{z}$ materiału faktograficznego, zawartego w księdze czynności pontyfikalnych kardynała Lipskiego, winna mieć świadomość, iż świadectwa te warto skonfrontować z innymi współczesnymi przekazami, jak również z literaturą przedmiotu, co zresztą stanowi zabieg pożądany w przypadku każdego źródła - nawet uchodzącego za wysoce wiarogodne.

Skądinąd jednak o ile w przypadku znanych postaci życia społecznego i religijnego, a na szczęście ich właśnie dotyczą w znacznej mierze zapiski z działów Benedictiones matrimoniales i Suffragia pro defunctis prezentowanego zabytku, zazwyczaj nie jest trudno skorygować błędne daty, tym bardziej zaś poprawić omyłkowo podane lub uzupełnić w przypadku braku takowych, o tyle w odniesieniu do „bohaterów drugiego planu” bywa z tym nieraz kłopot. W poniższej edycji stosowny materiał porównawczy wraz $\mathrm{z}$ aparatem krytycznym zamieszczono w przypisach, przy czym nie do każdej zapiski odnosi się odrębny przypis, albowiem tam, gdzie mamy do czynienia akurat z osobami mało znanymi (lub w ogólności nieznanymi), nienotowanymi w podstawowych kompendiach genealogiczno-heraldycznych czy w specjalistycznych słownikach biograficznych, a w konsekwencji informacji o nich należałoby poszukiwać w innych współczesnych materiałach źródłowych (najczęściej zresztą niewydanych dotychczas drukiem), piszący te słowa zdecydował się poprzestać na samym tylko opublikowaniu danego świadectwa, bez jego objaśniania i opatrywania komentarzem rzeczowym.

${ }^{21}$ AKapMK, sygn. LA 36, s. 5. Zastanawia fakt mechanicznego przejęcia tychże błędnych danych i bezkrytycznego ich przytoczenia w swej książce przez J. Bendyka, który widocznie nie dostrzegł wadliwości tekstu źródłowego i - co więcej - liczbę omyłek jeszcze powiększył, przemianowując Adama Franciszka Rostkowskiego na Adama Potockiego! - Bendyk, Działalność duszpasterska, s. 17 („Na biskupa został konsekrowany [...] przez prymasa Teodora Potockiego [...] w asyście biskupów: Andrzeja Załuskiego, Mikołaja Wesela, Adama Potockiego i Józefa Sołtyka"). Por. Prokop, Sukcesja święceń biskupich pasterzy Kościoła krakowskiego w XVIII stuleciu, s. 526, 547. 
Godzi się na koniec zwrócić uwagę czytelnika na to, o jakich szczególnie eksponowanych lub też związanych z Krakowem i Małopolską postaciach znajdzie on świadectwa w zaprezentowanym poniżej materiale. I tak w Liber sufragiorum pro defunctis nie mogło zabraknąć wpisów odnoszących się do uroczystości żałobnych po śmierci króla Augusta II Wettyna (zmarł 1 II 1733 w Warszawie) oraz owego pamiętnego w dziejach ówczesnego Krakowa potrójnego pogrzebu w styczniu 1734 r., kiedy to w katedrze na Wawelu pochowano nie tylko pierwszego Sasa na polskim tronie, ale również Jana III Sobieskiego i jego małżonkę Marię Kazimierę d'Arquien ${ }^{22}$. Wspomniane zostały tam również egzekwie (czy też aniwersarze) m.in. papieża Klemensa XII († 6 II 1740), który w roku 1737 kreował J.A. Lipskiego kardynałem, prymasa Teodora Andrzeja Potockiego $(† 17$ XI 1738), z którego rąk późniejszy purpurat przyjął sakrę, poprzedniego pasterza diecezji krakowskiej Konstantego Felicjana Szaniawskiego (†2 VII 1732) czy też przedstawiciela jakże znacząco zapisanego $\mathrm{w}$ dziejach miasta u stóp Wawelu rodu, starosty brzesko-kujawskiego Marka Szembeka, pochowanego 24 VII 1742 w podziemiach krakowskiego kościoła franciszkanów-reformatów. W tejże samej świątyni, zaledwie dwa tygodnie wcześniej (10 VII 1742), spoczął będący zresztą tercjarzem franciszkańskim wojewoda poznański Antoni Józef Poniński, współczesnym znany również jako marszałek konfederacji warszawskiej z czasów rywalizacji o tron polski z lat 1733-1734, potomnym zaś jako poeta łaciński, o którym w Acta pontificia J.A. Lipskiego czytamy zresztą aż dwukrotnie - nie tylko mianowicie w kontekście egzekwii, ale również z racji jego małżeństwa z przedstawicielką dopiero co wspomnianego rodu Szembeków, który to związek pobłogosławił ówczesny biskup krakowski²3.

Przeszliśmy tym samym do zapisek zawartych w dziale Liber benedictionum matrimonialium. Pojawiają się tam nazwiska tak znanych rodzin, należących do ówczesnej magnaterii Rzeczypospolitej Obojga Narodów, jak Braniccy, Czapscy, Potoccy, Przebendowscy, Rzewuscy, Sanguszkowie, Tarłowie czy w szczególniejszy sposób zapisani w dziejach Krakowa Wielopolscy ${ }^{24}$ i kilkakrotnie już tu wspominani Szembekowie ${ }^{25}$ (o wychodzących za mąż Szembekównach czytamy mianowicie dwukrotnie), a obok nich także Dąmbscy, Dembińscy, Lipscy (krewniacy kardynała), Oborscy, Ożarowscy, Pociejowie czy Szaniawscy. W gronie tym natrafiamy na przedstawicieli małopolskich (i nie tylko małopolskich) elit urzędniczych doby saskiej, na czele $\mathrm{z}$ wpierw wojewoda, a następnie kasztelanem krakowskim Janem Klemensem Branickim $(† 1771)$, dalej wojewodą lubelskim Janem Tarłą († 1754), wojewodą inowrocławskim Andrzejem Moszczeńskim (†

${ }^{22}$ Zob. niżej literaturę wskazaną w przyp. 49.

${ }^{23}$ E. Szklarska, Poniński Antoni Józef herbu Łodzia (zm. 1742), instygator koronny, marszatek konfederacji warszawskiej, wojewoda poznański, poeta łaciński, PSB, t. 27, s. 520-523.

${ }^{24}$ Zob. m.in. S. Cynarski, Początki kariery rodziny Wielopolskich, w: Spoleczeństwo staropolskie, t. 2, red. A. Wyczański, Warszawa 1979, s. 125-157. Także K. R. Prokop, Varia genealogiczne XVII-XVIII wieku ze staropolskich metryk kościelnych z Warszawy $i$ Wołczyna, „Biuletyn Biblioteki Jagiellońskiej”, 54 (2004) s. 162.

${ }^{25}$ Ostatnio o początkach rodu Szembeków i jego związkach z Krakowem pisał Z. Noga, Szembekowie krakowscy w XVI wieku, „Rocznik Krakowski”, 71 (2005) s. 77-91. 
1783), stolnikiem koronnym Ignacym Humieckim $(\dagger 1751)$ czy podczaszym krakowskim Arnolfem Dembińskim († 1758), którego wnukiem był znany z kart szkolnych podręczników historii generał Henryk Dembiński. Każdemu miłośnikowi ojczystej przeszłości, zainteresowanemu dziejami kraju za panowania dynastii Wettynów, wiele mówi też nazwisko wszechwładnego ministra saskiego Henryka Brühla, zarazem generała artylerii koronnej i kawalera Orderu Orła Białego, którego małżeństwo z czeską hrabianką Anną Marią Kolowrat-Krakowský pobłogosławił właśnie biskup Jan Aleksander Lipski. Podobną rolę odegrał on na ślubie w r. 1735 księcia Pawła Karola Sanguszki, marszałka wielkiego litewskiego, który dwa lata wcześniej wymieniany był jako jeden z kandydatów do tronu polskiego po śmierci Augusta II (nota bene poślubioną wówczas przez niego małżonką była poetka Barbara Urszula Duninówna). Trudno wreszcie nie zwrócić uwagi na zawarty w kościele opactwa benedyktynów na Świętym Krzyżu ślub starosty duninowskiego Jana Puszeta (Pugeta), niegdysiejszego rezydenta polskiego w Rzymie (1733), zarazem stronnika króla Stanisława Leszczyńskiego, z kasztelanką zawichojską Aleksandrą Marią ze Skarbek-Borowskich. Od tej to właśnie pary bierze swój początek owa gałąź innej spośród znacząco zapisanych w dziejach Krakowa rodzin, która w XIX w. zwiazzała swe losy ze stołecznym niegdyś miastem. Prawnukiem Jana i Aleksandry Marii był mianowicie Konstanty Judyt Puszet (Puget), dla którego w latach 1874-1875 wzniesiony został znany również współczesnym krakowianom Pałac Pugetów przy ul. Starowiślnej, tego zaś wnukiem - rzeźbiarz i pisarz Ludwik Puszet, autor m.in. Nowych kleynotów stołecznego miasta Krakowa (1901), natomiast jego z kolei synem - zmarły przed trzydziestu laty Jacek Jakub Puszet, profesor Akademii Sztuk Pięknych w Krakowie $^{26}$. By zaś wynikający z powyższego przeglądu obraz był kompletniejszy, wypada wspomnieć nadto słowem - wracając jeszcze na moment do działu Suffragia pro defunctis - o zapiskach odnoszących się do egzekwii księżnej Marii Karoliny de Bouillon († 1740), córki królewicza Jakuba Sobieskiego, a wnuczki króla Jana III, oraz oboźnego wielkiego Jerzego Marcina Ożarowskiego (†1741), ojca słynnego hetmana-targowiczanina, tudzież o jedynym w swej wymowie w całej owej księdze wpisie traktującym o śmierci i pogrzebie matki krakowskiego purpurata - Barbary z Miąskowskich Lipskiej († 1740), zmarłej w Kielcach, której w ostatniej drodze ów obdarzony godnością kardynalską syn towarzyszył ,non sine magno cordis dolore". Swoją rodzicielkę hierarcha ten przeżył o zaledwie pięć lat, umierając w sile wieku (w 56. roku życia) w niedzielę 20 II 1746. Nie wiemy natomiast, kiedy i w jakich okolicznościach dobiegł kresu żywot jego kapelana i sekretarza Jakuba Levisa, któremu zawdzięcza swe powstanie zaprezentowany

${ }^{26}$ M.in. M. Rożek, Puszet (du Puget-Puget) Jacek Jakub (1904-1977), rzeźbiarz, profesor Akademii Sztuk Pięknych w Krakowie, PSB, t. 29, s. 437-440; M. Rożek, Puszet (du Puget-Puszet, Puget) Ludwik (1877-1942), rzeźbiarz, pisarz, historyk sztuki, PSB, t. 29, s. 446-451 (oraz zamieszczone we wskazanym tomie Polskiego Stownika Biograficznego biogramy innych przedstawicieli rzeczonej rodziny). Także J. S. Dunin-Borkowski, Rocznik szlachty polskiej, t. 1, Lwów 1881, s. 431-432; J. S. Dunin-Borkowski, Almanach błękitny. Genealogia żyjących rodów polskich, Lwów [1908], s. 1106-1108. 
tu kodeks Acta pontificia, stanowiący ważne świadectwo do dziejów nie tylko XVIII--wiecznej diecezji krakowskiej ${ }^{27}$.

k. $68 r$

* $* * * * *$

\section{LIBER BENEDICTIONUM MATRIMONIALIUM}

k. $69 r$

Benedictiones matrimoniales ab Eminentissimo, Illustrissimo et REVERENDissimo

k. $70 r$

Domino, Domino JoANNe CARDINALI LipSKi PERACTAE

[1.] Anno Domini 1732, Feria $3^{\text {tia }}$ Pentecosten, Illustrissimus et Reverendissimus Dominus, Dominus Joannes in Lipe Lipski, episcopus Luceoriensis et Brestensis, Varsaviae, in solita palatii residentia, benedixit matrimonium Generosi Liminski cum Nagrodzka virgine, assistentibus proprio plebano atque aliis fide dignis testibus ${ }^{28}$.

[2.] Anno Domini 1733, die 9 Januarii, Varsaviae, [in capella S. Crucis collegiatae S. Joannis Baptistae], idem Illustrissimus et Reverendissimus Dominus Episcopus Luceoriensis benedixit matrimonium Illustrissimorum Joannis Tarło, palatini Lublinensis, cum Elisabetha de Braniciis Potocka, capitanea Sokalensis, etc ${ }^{29}$.

[3.] Eadem die in eadem capella S. Crucis collegiatae Varsaviensis idem Illustrissimus, Reverendissimus Dominus benedixit matrimonium inter Illustrissimos

${ }^{27}$ Warto w tym kontekście zwrócić uwagę czytelnika na zainicjowaną niegdyś przez ks. Jana Sygańskiego (1853-1918), związanego z Krakowem jezuitę, edycję świadectw metrykalnych z krakowskich archiwów kościelnych (parafii Mariackiej oraz katedry na Wawelu), która to ze wszech miar cenna inicjatywa nie doczekała się jednak jak dotychczas kontynuacji. - J. Sygański, Z dawnych metryk kościoła Mariackiego w Krakowie, Lwów 1911 [1912] (osobne odbicie z „Miesięcznika Heraldycznego", 3 (1910) s. 86-88, 113-120, 145-151, 177-184, 209-212).

${ }^{28}$ Zob. Boniecki, Herbarz polski, t. 14, s. 261; Uruski, Rodzina, t. 9, s. 51.

${ }^{29}$ Niesiecki, Herbarz polski, t. 9, s. 23 („Jan [Tarło] trzy razy śluby małżeńskie ponawiał: pierwszy raz z Marią Lubowiecka, starościanką oświęcimską, ale się to małżeństwo rozeszło, drugi raz z Elżbietą Modrzejowską, podskarbianką nadworną koronną, pozostałą wdową po Aleksandrze Łaszczu, wojewodzie bełzkim, trzeci raz z Elżbietą Branicką, wojewodzianką podlaską, która pierwej żyła z Ksawerym Potockim starostą sokalskim, wszakże z żadną potomstwa nie zostawił"). Także: W. Dworzaczek, Genealogia, cz. 2: Tablice, Warszawa 1959, tabl. 132 (Tarłowie), 152 (Braniccy); Por. K. Dobrska, Z dziejów kościoła Świętego Krzyża 1510-1995. Kalendarium, w: Ksiega pamiątkowa. Kościót Świętego Krzyża w Warszawie w trzechsetnq rocznicę konsekracji 1696-1996, red. T. Chachulski, Warszawa 1996, s. 168 (gdzie o tej oraz pozostałych odnotowanych w Acta pontificia kardynała J. A. Lipskiego uroczystościach, jakie miały miejsce w murach warszawskiego kościoła misjonarzy-lazarystów, brak wzmianki). 
Joannem Branicki, vexilliferem Regni, et Barbaram de Szembeciis Rzewuskam, pocillatricem Regni, in assistentia proprii parochi $\mathrm{i}^{30}$.

[4.] Anno ut supra, die 8 ${ }^{\text {va }}$ Augusti, in ecclesia praepositurali Rokitnensi, Celsissimus, Illustrissimus, Reverendissimus Dominus, Dominus Joannes Alexander in Lipe Lipski, episcopus Cracoviensis, dux Severiae, procancellarius Regni, benedixit matrimonium contractum inter Magnificos Dominos Sigismundum Linowski, succamerarium regium, et Mariannam Oborska, castellanidem Braclaviensem, in assistentia proprii parochi ${ }^{31}$.

[5.] Anno Domini 1734, die 27 Februarii, Cracoviae, in ecclesia S. Barbarae, idem Celsissimus Reverendissimus Dominus benedixit matrimonium Magnificorum [Antonii Josephi] Poninski, instigatoris Regni, et Annae de Szembeciis Wielopolska ${ }^{32}$.

${ }^{30}$ Niesiecki, Herbarz polski, t. 2, s. 282 (,Jan Branicki, późniejszy hetman wielki koronny, kasztelan krakowski [...], złączył się z Szembekówną, stolnikówną koronną, rozwódką Seweryna Rzewuskiego, referendarza koronnego; rozwiedziony z nią niedługim czasem"); S. K. Kossakowski, Monografie historyczno-genealogiczne niektórych rodzin polskich, t. 2, Warszawa 1860, s. 302; t. 3, Warszawa 1872, s. 251 (,[Barbara Szembekówna] była dwukrotnie zaręczana [sic], to z Sewerynem Rzewuskim, podczaszym koronnym, to z Janem Branickim, chorążym i hetmanem polnym koronnym"); W. Konopczyński, Branicki Jan Klemens herbu Gryf (1689-1771), hetman wielki koronny, PSB, t. 2, s. 404 („Straciwszy około r. 1730 pierwszą żonę [Katarzynę Radziwiłłównę], poślubił Barbarę Szembekównę, ale z nią wnet się rozwiódł”). Również: Żychliński, Złota księga, t. 1, s. 293; Uruski, Rodzina, t. 1, Warszawa 1904, s. 376 (Braniccy); t. 16, Warszawa 1931, s. 373 (Rzewuscy); Dworzaczek, Genealogia, cz. 2, tabl. 152 (Braniccy), 157 (Rzewuscy), 158 (Szembekowie); Prokop, Wiadomości genealogiczne, s. 215-216 (tamże przyp. 83). Należy dodać w tym miejscu, że Jan Branicki i Elżbieta z Branickich, o której w poprzedniej zapisce, byli rodzeństwem.

${ }^{31}$ Boniecki, Herbarz polski, t. 14, s. 274 („Zygmunt z Linowa i Piotrowic [Linowski], szambelan królewski, [był ożeniony] z Marianną Karoliną Oborską, kasztelanką bracławską [...]. Umarł bezdzietny w r. 1757, a wdowa jego [...] wyszła następnie za [Michała Aleksandra] Ronikera"). Zob. także: K. Niesiecki, Herbarz polski, t. 6, Lipsk 1841, s. 105 (Linowscy); t. 7, Lipsk 1841, s. 11, 14 (Oborscy); Z. Zielińska, Ronikier Michat Aleksander herbu Gryf (1728-1802), stronnik «Familii», generat wojsk koronnych, cześnik litewski, PSB, t. 32, s. 24.

${ }^{32}$ Małżonką Antoniego Józefa Ponińskiego była Salomea z Szembeków Dembińska, nie zaś Anna z Szembeków Wielopolska. Niesiecki, Herbarz polski, t. 7, s. 383-384; Kossakowski, Monografie historyczno-genealogiczne, t. 3, s. 266-267 (,[Salomea Szembekówna] naprzód żyła z Józefem Dębińskim, starostą wolbromskim, a gdy się to małżeństwo rozeszło, z Antonim Ponińskim, wojewodą poznańskim; w r. 1756 wstąpiła do wizytek w Warszawie"); Żychliński, Złota księga, t. 1, s. 300; t. 5, s. 219; Dunin-Borkowski, Almanach btękitny, s. 719; Szklarska, Poniński Antoni Józef, s. 521 („Dnia 25 II 1734 zawarł małżeństwo z Salomeą Szembekówną”), 523 („Drugą żoną [Antoniego Józefa Ponińskiego] była - od r. 1734 - Salomea z Szembeków, córka Antoniego Felicjana, podkomorzego krakowskiego. Jej pierwsze małżeństwo z Józefem Dembińskim, starostą wolbromskim, zostało unieważnione z powodu choroby umysłowej męża"). Także: Uruski, Rodzi$n a$, t. 14, s. 239; Dworzaczek, Genealogia, cz. 2, tabl. 158 (Szembekowie). 
[6.] Anno ut supra, die 19 Maii, in capella Morieburgensi, benedixit matrimonium contractum inter Illustrissimos Joannem de Brühl, comitem Saxonicum, et Annam Mariam Kolowrot [sic], comitissam ${ }^{33}$.

[7.] Anno Domini 1735, die 17 Aprilis, Varsaviae, in ecclesia Ordinis Minorum S. Francisci de Observantia, benedixit matrimonium contractum inter Celsissimum Principem Paulum Sanguszko et Illustrissimam Barbaram Duninuwna $[\mathrm{sic}]$, in assistentia proprii parochi ${ }^{34}$.

k. $70 v$

[8.] Anno Domini 1735, die $30^{\mathrm{ma}}$ Maii, Varsaviae, idem Celsissimus, Illustrissimus, Reverendissimus Dominus, in ecclesia collegiata Varsaviensi, benedixit matrimonium, in assistentia proprii parochi, Illustrissimorum Procopi Lipski, capitanei Srzemensis, cum Illustrissima Theresia Dąbska, mareschalci Regni Poloniae filia ${ }^{35}$

[9.] Anno Domini 1736, die 13 Julii, Varsaviae, in palatio Celsissimi Primatis Regni Theodori Potocki, archiepiscopi Gnesnensis, idem Celsissimus, Illustrissimus, Reverendissimus Dominus Episcopus Cracoviensis benedixit matrimonium Illustrissimorum [Ignatii] Huminiecki [sic], capitanei Lisiaticensis, palatinidae Podoliensis, cum Theresia Pociejowna, palatinida Vitebscensis; et quamvis Illustrissimus Neosponsus habet maiorem partem bonorum in diaecesi Cracoviensi, tamen assistebat Admodum Reverendus chori hebdomadarius ecclesiae insignis collegiatae Varsaviensis Illustrissimus [Venceslaus Hieronymus] Sierakowski, custos coronarum Regni, canonicus cathedralis Cracoviensis, curatus praepositus bonorum Illustrissimi Neospon$\mathrm{si}^{36}$.

${ }^{33}$ Chodzi o Henryka Brühla, a nie Jana. Niesiecki, Herbarz polski, t. 2, s. 321 („Żoną tego ministra [została] Marianna hrabianka z Kollowratów, urodzona dnia 2 IV 1717 roku"); W. Konopczyński, Brühl Henryk (1700-1763), minister-faworyt Augusta III, PSB, t. 3, s. 17 („17 IV 1737 poślubił Marię Annę hrabiankę Kolowrat-Krakowską, damę wielkich przymiotów towarzyskich"). Także: Boniecki, Herbarz polski, t. 3, s. 155; Uruski, Rodzina, t. 2, s. 13.

${ }^{34}$ Brak w zapisce informacji o urzędach i godnościach piastowanych przez P. K. Sanguszkę, który w tym czasie był już od przeszło roku marszałkiem wielkim litewskim (także kawalerem Orderu Orła Białego). Niesiecki, Herbarz polski, t. 8, s. 240-241; Żychliński, Złota księga, t. 5, s. 297; R. Marcinek, Sanguszko Pawet Karol, ksiażę (1680-1750), podskarbi nadworny litewski, marszatek nadworny, a nastęnie wielki litewski, PSB, t. 34, s. 499-500; E. Aleksandrowska, Sanguszkowa z Duninów Barbara Urszula (1718-1791), marszałkowa litewska, poetka, tlumaczka, filantropka, PSB, t. 34, s. 517 („W wieku 17 lat została trzecią żoną dobiegającego sześćdziesiątki marszałka wielkiego litewskiego księcia Pawła Karola Sanguszki, wyszukaną mu przez nadwornego lekarza dla podtrzymania wygasającego rodu Sanguszków. Ślub odbył się 17 IV 1735 w kościele franciszkanów w Warszawie; udzielił go biskup krakowski Andrzej Stanisław Załuski [sic]"). Także Dworzaczek, Genealogia, cz. 2, tabl. 173 (Sanguszkowie).

${ }^{35}$ Żychliński, Złota księga, t. 1, s. 57, 141; Boniecki, Herbarz polski, t. 14, s. 322; Uruski, Rodzina, t. 9, s. 93 (gdzie żonie Prokopa Lipskiego przydano imię Jadwiga).

${ }^{36}$ Niesiecki, Herbarz polski, t. 4, s. 395 („,Ignacy Humiecki, stolnik koronny, z Pociejówną żył bezdzietny”); t. 7, s. 338 (,Teresa Pociejówna zaślubiona [była] wojewodzicowi podolskiemu Igna- 
[10.] Anno Domini 1737, die 10 Octobris, Kielciis, in ecclesia collegiata Kielcensi, idem Celsissimus, Illustrissimus, Reverendissimus Dominus benedixit matrimonium Illustrissimorum, Magnificorum Stanislai Szaniawski, capitanei Augustoviensis, et Angelae Włynska ${ }^{37}$.

[11.] Anno Domini 1739, die 6 $6^{\text {ta }}$ Septembris, in Mogiła, idem Eminentissimus, Illustrissimus, Reverendissimus Dominus, in ecclesia Mogilensi Ordinis Cisterciensis, benedixit matrimonium contractum inter Joannem Gieppert et Salomeam Barszczowna, virginem.

[12.] Anno Domini 1740, die $11^{\mathrm{ma}}$ Decembris, Varsaviae, idem Eminentissimus, Illustrissimus, Reverendissimus Dominus, in ecclesia collegiata Varsaviensi, in assistentia proprii parochi, benedixit matrimonium Illustrissimorum Antonii Potocki, capitanei Kołomyiensis, et Mariannae Czapska, virginis, Illustrissimi [Joannis] Czapski, thesaurarii Regni, filiae ${ }^{38}$.

[13.] Anno Domini 1742, die 8 Aprilis, Cracoviae, in capella palatii sui, Eminentissimus et Reverendissimus Dominus benedixit matrimonium Magnificorum Dominorum Ignatii Łonowski, secretarii sui, et Joannae Ziomkowska, praesentibus Illustrissimis [Josepho] Mnisech, mareschallo Regni, Josepho Potocki, supremo duce exercituum, ac aliis ex equestri ordine quam plurimis $^{39}$.

[14.] Anno ut supra, die [pozostawiono puste miejsce na wpisanie dnia i miesia$c a$, in Wilkow, idem Eminentissimus, Illustrissimus et Reverendissimus

cemu Humieckiemu, stolnikowi koronnemu”); Żychliński, Złota księga, t. 10, s. 250 (,[Kazimierz Aleksander Pociej] pozostawił córkę Teresę za Ignacym Humieckim, herbu Junosza, stolnikiem koronnym, wojewodzicem podolskim i starostą bracławskim, zmarłym w 1751 r.”). Także Uruski, Rodzina, t. 5, s. 231; Dworzaczek, Genealogia, cz. 2, tabl. 182 (Pociejowie); A. Sowa, Pociej Kazimierz Aleksander herbu Waga (1666-1728), kasztelan witebski, nastęnie trocki, potem wojewoda witebski, PSB, t. 27, s. 34-35.

${ }^{37}$ Zob. Niesiecki, Herbarz polski, t. 7, s. 116 („Dwie rodzone siostry kardynała [Jana Aleksandra Lipskiego] były, jedna za Włyńskim, druga za Mielęckim”), por. s. 114 (gdzie czytamy, iż były to Marianna Włyńska i Konstancja Mielęcka, secundo voto Nowomiejska); t. 8, s. 601 (Szaniawscy); t. 9, s. 377 (Włyńscy).

${ }^{38}$ Niesiecki, Herbarz polski, t. 3, s. 180; t. 7, s. 442; Kossakowski, Monografie historyczno-genealogiczne, t. 1, s. 77 (,[Maria z Czapskich była] primo voto za Antonim Potockim, starostą kołomyjskim, synem Stanisława, wojewody poznańskiego, i Marii Łaszczówny, wojewodzianki bełzkiej, secundo voto za Tomaszem Czapskim, starostą knyszyńskim”); t. 2, s. 186 („,[Antoni Potocki był] żonaty (1740) z Marianną Czapską, podskarbianką koronną. Zmarł bezpotomnie"); Żychliński, Zlota księga, t. 11, s. 60 („Maria Czapska primo voto była za Antonim Potockim herbu Pilawa, starostą kołomyjskim, zmarłym bezpotomnie, [...] secundo voto za stryjem przyrodnim Tomaszem Czapskim, starostą knyszyńskim”); t. 14, s. 36 („Antoni Potocki, starosta kołomyjski, zaślubił w r. 1740 w Warszawie Mariannę Czapską, córkę Jana Ansgarego, podskarbiego wielkiego koronnego"); Boniecki, Herbarz polski, t. 3, s. 279-280 (,[Maria z Czapskich była] primo voto za Antonim Potockim, starostą kołomyjskim; następnie wyszła za swego stryja Tomasza Czapskiego").

${ }^{39}$ Por. Boniecki, Herbarz polski, t. 15, s. 376 („Ignacy Łonowski, stolnik brzeski, sekretarz prymasa Komorowskiego"); Uruski, Rodzina, t. 9, s. 356. 
Dominus, in assistentia proprii parochi, copulavit matrimoniali foedere Illustrissimos Josephum [Antonium] Lipski, castellanum Bełscensem, et [pozostawiono puste miejsce na wpisanie imienia] Skałaska, virginem, castellanidem Gnesnensem ${ }^{40}$.

[15.] Anno ut supra, die 10 Junii, Cracoviae, in ecclesia archipresbyterali, idem Eminentissimus, Illustrissimus, Reverendissimus Dominus, horis postmeridianis, matrimoniali coniunxit vinculo Magnificos Dominos Michaelem Klimowicz et Theresiam Rudzka ${ }^{41}$.

[16.] Anno ut supra, die 30 Julii, Cracoviae, in ecclesia archipresbyterali, idem Eminentissimus, Illustrissimus, Reverendissimus Dominus, horis postmeridianis, benedixit matrimonium contractum inter Illustrissimos, Magnificos Dominos Stanislaum Dąbski et Agnetem Tęgoborska, virginem, capitanei Bochnensis filiam ${ }^{42}$.

[17.] Anno Domini 1745, die 31 Januarii, in villa Szczeczno, idem Eminentissimus, Illustrissimus, Reverendissimus Dominus matrimonium contractum inter Magnificos Dominos Felicianum Kossowski, vicesgerentem castrensem Sandomiriensem, et Mariannam Kochanowska, virginem, castellani Radomiensis filiam, benedixit et confirmavit ${ }^{43}$.

[18.] Anno ut supra, die 23 Maii, apud S. Crucem in monasterio Calvo Montano Ordinis S. Benedicti, idem Eminentissimus, Illustrissimus et Reverendissimus Dominus, horis matutinis, ratificavit matrimonium contractum inter Magnificos Dominos Joannem de Pugett, capitaneum Duninoviensem, et Alexandram de Borowskie Dziulina ${ }^{44}$.

[19.] Anno Domini 1745, die 24 Octobris, Cracoviae, in ecclesia archipresbyterali ad S. Mariam in Circulo, horis pomeridianis, Eminentissimus, Celsissi-

${ }^{40}$ Żychliński, Złota księga, t. 1, s. 147; t. 16, Poznań 1894, s. 161 („Franciszek Skaławski, kasztelan gnieźnieński, pozostawił trzy córki, [a wśród nich] Wiktorię, zmarłą 4 III 1783 bezdzietnie, za Józefem Lipskim herbu Grabie, kasztelanem łęczyckim"); Boniecki, Herbarz polski, t. 14, s. 326 („Z drugą żoną, Wiktorią Skaławską, kasztelanką gnieźnieńską, [nie miał potomstwa]”); A. Sowa, Lipski Józef herbu Grabie (ok. 1686-1752), poset na sejmy, kasztelan betski i łęczycki, PSB, t. 17, s. 433-434. Także: Niesiecki, Herbarz polski, t. 6, s. 112; t. 8, s. 375.

${ }^{41}$ Por. Sygański, Z dawnych metryk, s. 45 („,Klimowicz Michał, generosus, cześnik smoleński, [zawarł ślub] z Teresą Rudzką, pokojową Ludwiki Potockiej, wojewodziny kijowskiej, 11 VI 1742. Świadkowie: Józef z Wielkich Kończyc Wandalin Mniszech, kasztelan krakowski; Józef z Potoka Potocki, wojewoda kijowski, hetman wielki koronny, i inni”). Także: Boniecki, Herbarz polski, t. 10, s. 139 (gdzie informacja, iż Michał Klimowicz był „komisarzem biskupa krakowskiego”; jako jego żona wspomniana tam została wyłącznie Marianna z Jankowskich); Uruski, Rodzina, t. 6, s. 390 .

${ }^{42}$ Por. Sygański, Z dawnych metryk, s. 42 („Dąbski Stanisław, magnificus, miecznikowicz czerski, [zawarł ślub] z Barbarą Tęgoborską, starościanką bocheńską, 31 VII 1742. Świadkowie: Karol Gonzaga de Wielopolskie, margrabia na Mirowie Myszkowski, koniuszy koronny, starosta krakowski; Jan hrabia na Żywcu i Pieskowej Skale Wielopolski, starosta żarnowski”). Por. Boniecki, Herbarz polski, t. 4, s. 166, 173-174.

${ }^{43}$ Por. Niesiecki, Herbarz polski, t. 5, s. 141; Boniecki, Herbarz polski, t. 10, s. 285.

${ }^{44}$ Dunin-Borkowski, Almanach blękitny, s. 1106. 
mus, Illustrissimus et Reverendissimus Dominus Joannes Alexander a Lipe Lipski, episcopus Cracoviensis, dux Severiae, benedixit matrimonium contractum inter Magnificos Dominos Arnolphum Dębinski, pocillatorem Cracoviensem, et Cunegundem [sic] Aksakowna, virginem, filiam pie defuncti Magnifici [Martiani] Aksak, comitis in Tarnow dapiferi, praesentibus Illustrissimis et Magnificis Dominis [Carolo] Wielopolski, praefecto Stabuli Regni, et [Laurentio] Lanckoroński, capitaneo Stopnicensis, et alii quam plurimis ex equestri ordine ${ }^{45}$.

[20.] Anno eodem, die 24 Novembris, Cracoviae, idem Eminentissimus, Celsissimus, Illustrissimus et Reverendissimus Dominus, in capella palatii sui, ratificavit matrimonium contractum inter Magnificum Dominum Andream Moszczenski, capitaneum Brestensem Cuiaviensem, et Illustrissimam Elisabeth [Przebendowska], Illustrissimi [Petri Georgii] Przebendowski, palatini Marienburgensis, filiam, post fata vero Illustrissimi [Georgii Martini] Ozarowski, castrorum Regni praefecti, relictam viduam, praesentibus Illustrissimis et Magnificis [Carolo Wielopolski], praefecto Stabuli Regni et fratre eius [Joanne Wielopolski], pincerna Regni, atque [Hieronymo Wielopolski], capitaneo Zarnowecensi, et aliis ex equestri ordine quam plurimis ${ }^{46}$.

[21.] Anno 1746, die 14 Januarii, idem Eminentissimus, Illustrissimus et Reverendissimus Dominus benedixit matrimonium contractum inter Magnificos [pozostawiono puste miejsce na wpisanie imienia] Laskowski et Rosaliam Klimowiczowna, virginem, praesentibus Illustrissimis et Magnificis Dominis capitaneis Lipnicensi et Stęzycensi, et aliis quam plurimis ex equestri ordine. [dopisane później] In collegiata Kielcensi ${ }^{47}$.

[22.] Anno eodem, die [brak cyfry na oznaczenie daty dziennej] Februarii, idem Eminentissimus, Illustrissimus et Reverendissimus Dominus ratificavit matrimonium contractum inter Magnificos [puste miejsce na wpisanie imienia] Mierzynski et [puste miejsce na wpisanie imienia] Waligorska, viduam,

${ }^{45}$ Żychliński, Złota księga, t. 4, s. 60; Boniecki, Herbarz polski, t. 4, s. 201 („Pierwszą żoną [Arnolfa Dembińskiego] była w r. 1726 Marianna Bobrownicka, chorążanka bracławska. [...] Drugi raz ożenił się w r. 1745 z Kunegundą Aksakówną, podczaszanką żytomierską"). Por. Sygański, $Z$ dawnych metryk, s. 43 („Dębiński Arnolf, magnificus, podczaszy krakowski, [zawarł ślub] z Kunegundą Aksakówną, 24 X 1745" [brak informacji o świadkach]). Nadto Niesiecki, Herbarz polski, t. 2 , s. 17.

${ }^{46}$ Żychliński, Złota księga, t. 19, s. 84 (,,[Andrzej Moszczeński był] ożeniony z Elżbietą z Przebendowa Przebendowską herbu własnego, wojewodzianką malborską”); t. 28, s. 61 („Elżbieta Przebendowska oddała rękę Andrzejowi Moszczeńskiemu herbu Nałęcz, wojewodzie inowrocławskiemu, panu na Żołędowie"); H. Dymnicka-Wołoszyńska, Moszczeński Andrzej herbu Nałęcz (1717-1783), poset na sejmy, kasztelan, a nastęnie wojewoda inowrocławski, PSB, t. 22, s. 94 („Był żonaty z Urszulą Elżbietą Przebendowską, wojewodzianką malborską, wdową po Jerzym Ożarowskim, oboźnym wielkim koronnym”). Por. Sygański, Z dawnych metryk, s. 48 („Moszczyński Andrzej, magnificus, starosta brzesko-kujawski, [zawarł ślub] z Elżbietą z Przebendowskich Ożarowska, wdowa, 24 XII 1745, in capella palatii cardinalis Joannis Lipski" [brak informacji o świadkach]).

${ }^{47}$ Zob. wyżej przyp. 41 (Michał Klimowicz). 
praesentibus Illustrissimis capitaneis Lipnicensi et Stęzycensi, et aliis ex equestri ordine quam plurimis. In collegiata Kielcensi.

$* * * * *$

k. $85 r$

\section{LIBER SUFFRAGIORUM PRO DEFUNCTIS}

k. $86 r$

[1.] Anno Domini 1732, die 9 Junii, Varsaviae, in ecclesia S. Crucis Congregationis Missionum, Illustrissimus et Reverendissimus Dominus Joannes Alexander in Lipe Lipski, episcopus Luceoriensis, absolvit missam pontificalem pro anima Joannis Tarło, episcopi Posnaniensis.

[2.] Anno ut supra, die 5 Novembris, in ecclesia parochialis Janoviensi [Janów Podlaski], idem Illustrissimus, Reverendissimus Dominus, post solemnes exequias praedecessori suo factas, olim Stephano Rupniewski, missam pontificaliter persolvit.

[3.] Anno Domini 1733, die 5 Februarii, Varsaviae, in Arce Regia, idem Illustrissimus et Reverendissimus Dominus Joannes in Lipe Lipski, episcopus Cracoviensis, dux Severiae, procancellarius Regni Poloniae, ad Castrum mortui Serenissimi Augusti Secundi, regis Poloniae, pontificaliter missam canta$\mathrm{vit}^{48}$.

[4.] Anno Domini 1734, die 16 Januarii, Cracoviae, in ecclesia cathedrali Cracoviensi, idem Illustrissimus et Reverendissimus Dominus in exequiis Serenissimorum Poloniae regum Joannis III., Augusti II. et Mariae, reginae Poloniae, solemni pontificaliter cantata missa, ut procancellarius Regni, Requiem Doloris valedixit Castrum ${ }^{49}$.

[5.] Anno Domini 1734, die 5 Februarii, Dresdae in Saxonia, idem Illustrissimus, Reverendissimus Dominus die anniversaria obitus Serenissimi et Invictissimi Augusti Secundi pontificalem in Capella Arcis Dresdensis absolvit missam.

[6.] Anno Domini 1735, die 20 Maii, Varsaviae, in ecclesia Patrum Carmelitarum Discalceatorum, idem Illustrissimus et Reverendissimus Dominus in funere Magnifici Domini [Floriani] Dębowski, iudicis Plocensis, missam pontificaliter cantatam et caeremonias conductus maioris explevit ${ }^{50}$.

${ }^{48}$ Zob. J. Staszewski, August II Mocny, Wrocławs. 278. Por. B. Przybyszewski, Fabrica ecclesiae Cracoviensis. Materiaty źródtowe do dziejów katedry krakowskiej w XVIII wieku z archiwaliów kapitulnych kurialnych krakowskich, Kraków 1993, s. 62, nr 135.

${ }^{49}$ M.in. Rożek, Uroczystości w barokowym Krakowie, s. 165-168; Staszewski, August III Sas, s. 153; Kronika Krakowa, s. 122; Skowron, Wawel. Kronika dziejów, t. 1, s. 227. Por. Przybyszewski, Fabrica ecclesiae Cracoviensis, s. 63, nr 137.

${ }^{50}$ Boniecki, Herbarz polski, t. 4, s. 240 („Urodzony 1647 roku, zmarł 13 V 1735 w Warszawie"); Uruski, Rodzina, t. 3, s. 142. Do dziejów świątyni karmelitów bosych w Warszawie zob. B. J. Wanat, Zakon karmelitów bosych w Polsce. Klasztory karmelitów i karmelitanek bosych 1605- 
[7.] Anno Domini 1735, die 21 Maii, Varsaviae, in ecclesia collegiata, idem Illustrissimus et Reverendissimus Dominus anniversariam ducum Austriae obeundo diem, cantatam pontificaliter absolvit missam.

[8.] Anno eodem, die 12 Decembris, Varsaviae, in ecclesia Patrum Franciscanorum, idem Illustrissimus et Reverendissimus Dominus celebravit in exequiis missamque cantavit pro anima Magnifici Domini [Sigismundi] Dąbski, capitanei Dibowscensis ${ }^{51}$.

[9.] Anno Domini 1736, die 28 Januarii, in ecclesia collegiata Kielcensi, idem Illustrissimus et Reverendissimus Dominus celebravit pontificaliter in exequiis anniversariis Reverendissimi antecessoris sui Feliciani Szaniawski ${ }^{2}$.

[10.] Anno Domini 1738, die 23 Novembris, Varsaviae, idem Eminentissimus, Illustrissimus, Reverendissimus Dominus celebravit pontificaliter missam ad Castrum Illustrissimi Theodori Potocki, archiepiscopi Gnesnensis, primatis Regni, eumque in solemni exportatione praevio conductu maiori benedixit ${ }^{53}$.

[11.] Anno Domini 1740, die 23 Februarii, Kielciis, idem Eminentissimus, Illustrissimus, Reverendissimus Dominus, deflendo fata Sanctissimi Domini nostri Papae de antiquissima familia Corsinorum Clementis XII., pontificaliter missam cantatam celebravit.

[12.] Anno ut supra, die 14 Novembris, Varsaviae, in ecclesia Sancti Casimiri monialium a continua Sanctissimi Sacramenti adoratione, sakramentki dictarum, idem Eminentissimus Cardinalis in exequiis Celsissimae ducissae [Mariae Carolinae] de Bulion missam pontificaliter cantatam celebravit ${ }^{54}$.

[13.] Anno ut supra [pozostawiono puste miejsce na wpisanie dnia i miesiqca], obiit Illustrissima Barbara de Miąskowskie Lipska, mater Eminentissimi Cardinalis, cuius cor in ecclesia collegiata Kielcensi conditum, corpus vero iuxta illius ultimam voluntatem in Maiorem Poloniam translatum est ac sepultum in ecclesia Patrum Reformatorum $[\boldsymbol{k} .87 \boldsymbol{r}]$ ad Calissiam in villa $[p o-$ zostawiono puste miejsce na wpisanie nazwy] manentium. Ipso die exportationis Eminentissimus, Illustrissimus, Reverendissimus Cardinalis pia matri suae ex filiali amore ponens suffragia, missam pontificaliter cantatam ac

-1975, Kraków 1979, s. 403-457 (gdzie na s. 448-452 zestawione kalendarium wydarzeń - m.in. w oparciu o kronikę klasztorną).

${ }^{51}$ Niesiecki, Herbarz polski, t. 3, s. 297; Żychliński, Złota księga, t. 1, s. 57; Boniecki, Herbarz polski, t. 4, s. 161.

${ }^{52}$ Por. Przybyszewski, Fabrica ecclesiae Cracoviensis, s. 56-58, nr 127.

${ }^{53}$ Por. J. Korytkowski, Arcybiskupi gnieźnieńscy, prymasowie i metropolici polscy od roku 1000 aż do roku 1821, t. 4, Poznań 1891, s. 537 (2 wyd.: t. 16, Poznań 2005, s. 309-310).

${ }^{54}$ Kossakowski, Monografie historyczno-genealogiczne, t. 3, s. 209; J. Poraziński, Sobieski Jakub Ludwik (1667-1737), królewicz, PSB, t. 39, s. 494-495. Obszerniejszy opis tamtego pogrzebu, skreślony w oparciu o dziś już nieistniejącą kronikę klasztorną warszawskich sakramentek (tamtejsze archiwalia spłonęły w r. 1944), zawarty został w edycji: Benedyktynki od Nieustajacej Adoracji Najświętszego Sakramentu w Warszawie 1688-1938, Warszawa 1938, s. 133-135. 
conductum maiorem absolvit pastoralique munitam benedictione in viam pacis et prosperitatis non sine magno cordis dolore expedire permisit.

[14.] Anno Domini 1741, die 20 Novembris, Pinczoviae, in ecclesia Patrum Reformatorum, idem Eminentissimus, Illustrissimus, Reverendissimus Dominus in exequiis Illustrissimi [Georgii Martini] Ozarowski, castrorum metatoris Regni, capitanei Neocorcinensis et Dobczycensis, pontificaliter missam cantatam absolvit ${ }^{55}$.

[15.] Anno Domini 1742, die 19 Julii, Cracoviae, in ecclesia Patrum Reformatorum, idem Eminentissimus, Illustrissimus, Reverendissimus Dominus in exequiis Illustrissimi olim [Antonii Josephi] Łodzia Poninski, palatini Posnaniensis, pontificaliter missam cantatam absolvit, caeremoniasque conductus maioris explevit ${ }^{56}$.

[16.] Anno ut supra, die 20 Augusti, Cracoviae, idem Eminentissimus, Illustrissimus, Reverendissimus Dominus, in ecclesia Patrum Reformatorum, in exequiis Illustrissimi olim Marci Szembek, capitanei Brestensis etc., pontificaliter missam cantatam ac caeremonias conductus maioris absolvit ${ }^{57}$.

${ }^{55}$ Zob. Żychliński, Zlota księga, t. 16, s. 112 (tamże, na s. 100-112, obszernie o życiu J. M. Ożarowskiego); Dunin-Borkowski, Almanach btękitny, s. 683-684; E. Burda, Ożarowski Jerzy Marcin herbu Rawicz (ok. 1690-1741), oboźny wielki koronny, poseł na sejm, PSB, t. 24, s. 670 (,Zmarł w r. 1741. Pochowany został 11 IV tr. w Pińczowie, w grobach Myszkowskich w kościele reformatów”). Ogólnie do dziejów kościoła i klasztoru franciszkanów-reformatów w Pińczowie: A. Sroka, Sanktuarium Matki Bożej Mirowskiej w Pińczowie, oprac. A. Mitkowska, Kraków 1990.

${ }^{56}$ Zob. M. Wilczyński, Klasztor świętego Kazimierza OO. Reformatów w Krakowie, Kraków 1893, s. 246 (Nekrologia dobrodziei pochowanych pod kościołem naszym w Krakowie): „1742, dnia 10 lipca. Andrzej Łodzia Poniński, wojewoda poznański, nasz tercjarz"; Szklarska, Poniński Antoni Józef herbu Łodzia, s. 523 (,Zmarł 8 VII 1742 we wsi Wola pod Krakowem (prawdopodobnie Wola Justowska); zgodnie ze swoim testamentem pochowany został w kościele reformatów w Krakowie”). Także Żychliński, Złota księga, t. 5, s. 219; Dunin-Borkowski, Almanach błękitny, s. 719.

${ }^{57}$ Zob. Wilczyński, Klasztor świętego Kazimierza, s. 246: „1742, dnia 24 lipca. Marek Szembek, starosta brzesko-kujawski”. Także Kossakowski, Monografie historyczno-genealogiczne, t. 3, s. 269-270 („Życie zakończył jako generał-major Jego Królewskiej Mości i starosta brzesko-kujawski w r. 1744 [sic]”); Żychliński, Zlota ksiega, t. 1, s. 301 („Umarł 1744 roku”); Dworzaczek, Genealogia, cz. 2, tabl. 158 (Szembekowie) [gdzie tak samo rok 1744, jako data zgonu]. 